психоемоційний фон, підтримка інтересу, формування інтелектуального потенціалу і накопичення професійно значущих навичок, що згодом забезпечують активну творчо усвідомлену самостійну діяльність.

\title{
Література:
}

1. Комарова 3. И. Технология научных исследований в системной методологии современной лингвистики: учеб. пособие. Екатеринбург: Урал. го с. пед. ун-т, 2016. 209 с.

2. Сисоєва С. О. Інтерактивні технології навчання дорослих: навчально-методичний посібник. К. : ВД «ЕКМО», 2011. 324 с.

3. Llorens A., Berbegal-Mirabent J., Llinàs-Audet X. Aligning professional skills and active learning methods: an application for information and communications technology engineering. European Journal of Engineering Education. 2014. Vol. 42 (4). P. 382-395.

4. Yen C.-J., Sujo-Montes L., Roberts G. A. Gaming personality and game dynamics in online discussion instructions. Educational Media International. 2015. Vol. 52, Iss. 3. P. 155-172.

5. Yuretich R. F., Khan S. A., Leckie R. M. Active-Learning Methods to Improve Student Performance and Scientific Interest in a Large Introductory Oceanography Course. Journal of Geoscience Education. 2020. Vol. 49 (2). P. 111-119.

DOI https://doi.org/10.30525/978-9934-26-041-4-103

\section{СУЧАСНА ІНТЕРПРЕТАЦІЯ МЕТОДОЛОГІЇ МІЖПРЕДМЕТНИХ ЗВ'ЯЗКІВ У ВИЩІЙ ТЕХНІЧНІЙ ШКОЛІ}

\author{
Сергіснко Л. Г. \\ кандидат педагогічних наук, доцент, \\ доиент кафедри вищої математики і фізики \\ Державний вищий навчальний заклад \\ «Донецький національний технічний університет» \\ м. Покровськ, Донецька область, Украӥна
}

Актуальність теми. Сучасна педагогічна наука має в своєму розпорядженні достатньо різноманітних теоретичних та експериментальних даних, що підтверджують ефективність 
використання міжпредметних зв'язків у навчальному процесі. Ідея комплексного підходу до складання навчальних програм, наскрізного планування підготовки фахівців потрібного профілю, побудови мережевих графіків навчального процесу тощо - всі ці ідеї можуть бути реалізовані тільки на міжпредметній основі. Тому дана тематика $\epsilon$ сьогодні актуальною.

Основна частина. Особливе місце в педагогічних дослідженнях займають останнім часом питання, які вирішуються на основі міжпредметних зв'язків і з використанням структурно-логічних схем. Опубліковані статті виявляють широкий діапазон проблем, що вирішуються на цій основі. Прикладом можуть служити дослідження, які проводяться вже достатню кількість часу, зі створення навчальнометодичних комплексів різного рівня спільності, результати яких висвітлювалися, наприклад, в роботі В. Бевза [1, с. 11-15]. Аналогічний підхід здійснюється і в нашому університеті, проте цілі й завдання нашого дослідження дещо відрізняються від розглянутих робіт.

Знайомлячись 3 педагогічною та методичною літературою та знаючи практику організації навчального процесу у вищих технічних навчальних закладах, ми розуміли, що однією 3 причин слабкого функціонування міжпредметних зв'язків у навчальному процесі $\epsilon$ відсутність раціонального способу систематизації взаємопов'язаного матеріалу, зручного практично, як для викладача, так і студентів; необхідність великої попередньої роботи - аналізу навчальних програм і початкової систематизації взаємопов'язаного матеріалу. Тому ми хочемо поділитися розробленим нами способом систематизації матеріалу на прикладі викладання фізики, розкрити дидактичні та організаційні функції такого способу, а також методики ії викладання. Наш предмет, як відомо, $є$ в технічному університеті, одним з основних фундаментальних курсів. У роботі відомого дидакта В. Оконя робиться акцент на те, що недостатне знання фундаментальних дисциплін перешкоджає процесу професійної освіти, підкреслюється необхідність гармонії між професійним та спеціальним навчанням студентів у технічних вищих навчальних закладах [2]. Н.Ф. Тализіна підкреслює, що формування фахівця відбувається під комплексним впливом багатьох факторів, значення яких виявляється з позицій діяльнісного та компетентнісного підходів [3].

Обрану нами форму систематизації ми назвали тематичним блоком тобто, це звичайна структурно-логічна схема (СЛС). Такий блок утворюється однією з тем аналізованого навчального предмета (темою, яка визначає блок схеми) та всіма його істотними взаємозв'язками 3 темами інших навчальних предметів, враховуючи прикладний характер 
даної теми для спеціальних дисциплін (прикладной блок), див. рис.1. Визначальними в кожному з наших блоків $\epsilon$, природно, теми курсу фундаментальної дисципліни фізики i, відповідно, методики іiі викладання. Кожна така тема записується в центрі блоку (схеми); тут же даються номер і назва теми (відповідно ії номеру в робочій програмі), план іiі вивчення (тобто, по суті, структурно-логічний план лекції 3 урахуванням прикладного використання, яке необхідно студентам для вивчення спеціальних предметів) [1].

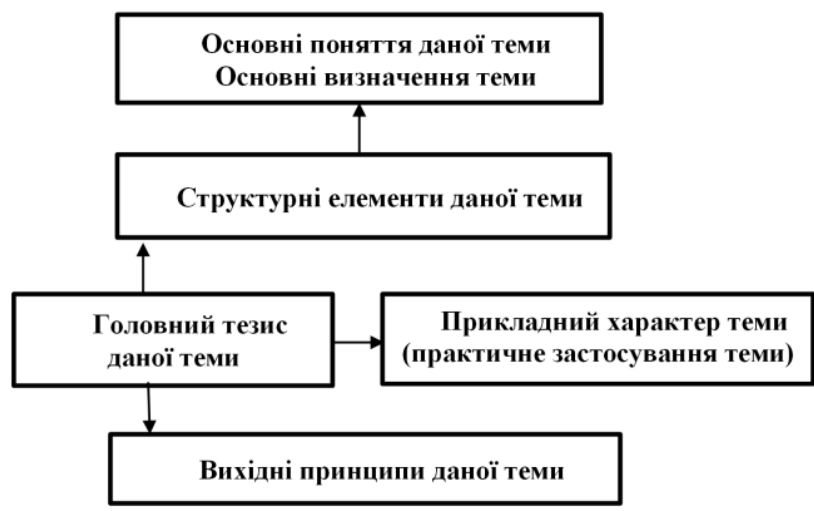

Рис. 1. Приклад побудови тематичного блоку

Зв'язок з темами математичних курсів не вказана, тому що блоки утворені темами 3 розділу загальної методики викладання фізики, а вони викладаються на прикладах 3 будь-якого розділу систематичного курсу математики, не маючи конкретного зв'язку з окремими темами. Для більшої наочності майже кожна тема доповнює супутню тему прикладного характеру, яка виділена в окремий компонент блоку; ці компоненти оформляються у вигляді прикладних компонент. У кожному блоці компонент проставляється номер, що відповідає номеру теми в навчальній програмі з даного предмета. Ця нумерація зручна для всієї подальшої роботи як викладача, та і студентів.

3 точки зору дидактики, система тематичних блоків, складена узгоджено стосовно до всіх тем кожної навчальної програми, тому служить ефективним методичним посібником для викладачів. Справді, знайомство з подібним блоком дає викладачеві, по-перше, конкретний матеріал для розкриття методології розглянутого питання. Компонентами блоку $є$ закони, категорії та положення фізики, на 166 
підставі яких формується, розкривається, вивчається та застосовується теорія фундаментальної та початкової професійної підготовки. Подруге, викладач бачить тут і теоретичну, і практичну базу даної теми, яка створюється раніше вивченими дисциплінами, наприклад, математикою, філософією, а також наступними спеціальними предметами, які будуть вивчатися пізніше; за компонентами блоку простежуються всі міжпредметні зв'язки досліджуваної теми та стає очевидною спільність термінологічного й понятійного апарату, змістовна взаємозумовленість курсів. Блок показує, які теми та поняття 3 навчальних предметів, які студентам належить вивчати, будуть базуватися на темі, яка визначає даний блок (міжпредметні зв'язки такого типу на малюнку не вказані, так як методика викладання предмета - це дисципліна, яка не $\epsilon$ профілюючою в технічних університетах). Це три основні напрямки, в яких блоки можуть бути використані в якості допомоги викладачеві в доборі матеріалу для лекцій та практичних занять, для різних видів завдань, які виконуються студентами самостійно.

Інший напрямок дидактичної значущості блоків - це використання ïx в якості наочних посібників на заняттях в аудиторії і поза нею. Оформлення компонентів у вигляді блоків спеціальної форми та виділення їх певним кольором (в робочих кресленнях блоків) дозволяє компактно згрупувати великий за обсягом і різноманітний за змістом фактичний матеріал, робить його легко доступним для огляду i наочним, a це допомагає сприйняттю логічної структури досліджуваного матеріалу. До дидактичних функцій тематичних блоків можна додати ще одну - сприяння формуванню наукового світогляду студентів. Наявність в блоках компонентів, які розкривають взаємозв'язок досліджуваного матеріалу з законами і категоріями фізики, математики, філософії, конкретно демонструє перед студентами той факт, що загально-методологічні принципи будь-якого наукового дослідження закладені в діалектичному та історичному матеріалізмі. Сукупність тематичних блоків кожного навчального предмета дає широкі можливості для відбору того чи іншого матеріалу, знайомого студентам 3 курсу фізики, математики, філософії, як методологічну основу досліджуваної теми. I розкриття основних положень цієї теми 3 опорою на міжпредметні знання вчить майбутнього фахівця методологічно обгрунтовувати розглянуту теорію або явище. 3 іншого боку, застосування тематичних блоків на заняттях 3 різних дисциплін виробляє у студентів навички виявлення взаємозв'язків в досліджуваному матеріалі, формує переконаність в необхідності такого підходу до всіх пізнаваємих явищ; привчає 
розглядати досліджувану теорію з різних позицій і простежувати будь якому явищі причинно-наслідкові зв'язки. Все це разом формує діалектичний стиль мислення у студентів.

Отже, систематизація фактичного матеріалу навчальних предметів в тематичні блоки допомагає, на наш погляд, вирішувати деякі змістовні, методичні та методологічні завдання у навчанні студентів вищих технічних навчальних закладів. Головне ж призначення тематичних блоків - практичне використання їх для складання структурно-логічних схем різних навчальних дисциплін. Наприклад, певним етапом систематизації матеріалу в циклі навчальних дисциплін, що забезпечують загальноінженерну та загальнотехнічну підготовку студентів нашого університету, стало складання структурно-логічних схем не тільки курсу фізики, але й курсів математики та інформатики.

Висновки. Зіставлення логічної схеми загального курсу фізики 3 наведеним, для приклада, тематичним блоком допомагає зрозуміти механізм використання тематичних блоків для складання та використання структурно-логічних схем.

Очевидно, що тематичні блоки допомагають не тільки складати структурно-логічні схеми курсів, але й використовувати їх для постановки навчального процесу на міжпредметній основі взагалі.

\section{Література:}

1. Бевз В. Міжпредметні зв'язки як необхідний елемент предметної системи навчання // Математика в школі - 2003. - № 6 - С. 11-15.

2. Оконь В. Введение в общую дидактику. М. : Высшая школа. 1990. - C. 142-162.

3. Талызина Н.Ф. Управление процессом усвоения знаний (психологические основы). - М. : Издательство МГУ, 1994. - Гл. 3. C. 146-198. 